\title{
AN ESSAY TOWARDS THE CLASSIFICATION OF HOMERIC COIN TYPES.
}

\author{
[Plate V.] \\ Pariunt desideria non traditos vullus, sicut in Homero evenit.-PLis.

\section{I.-The Relation of Greek Ideal Portraits and Numismatics. ${ }^{1}$}

In dealing with any ideal portrait it is well to remember a remark of Pliny's concerning the portraits of the poet Alcman, not that Alcman is represented on any coin we know of, but because the phrase throws light on the whole question: Alcman poeta nullius est nobilior [Calamidis] there is no nobler portrait of the poet Alcman than that by Calamis. ${ }^{2}$ This passage implies that Pliny knew portraits of Alcman by various sculptors and preferred that of Calamis ; nor is this surprising, if we consider the number of portraits of Homer and Sappho for example recorded by ancient writers. The obvious but often forgotten deduction to be drawn from the fact that different artists represented the same subject differently is, that it is not legitimate to assume that the identification of one type of portrait necessarily puts all other identifications out of court. When, for instance, the $\mathrm{Ny}$-Carlsberg Anacreon was identified, all other types were discarded; as Bernoulli puts it, "Mit der Auffindung der capitolinischen Herme sind natürlich die fruiher aufgestellten Anakreondeutungen sämtlich in Wegfall gekommen." (Gr. Ikon. i. p. 83.) Yet later representations of Anacreon existed, as the epigrams of Leonidas of Tarentum, Eugenes, ${ }^{3}$ and Theocritus ${ }^{4}$ show, and coins of 'Teos represent him not only in the attitude of the famous Athenian statue, ${ }^{5}$ but seated in flowing drapery, playing or holding the lyre. ${ }^{6}$ That other sculptors would have modelled their portraits on that of Cresilas

\footnotetext{
1 The word ideal is used throughout as equivalent to imaginary, not as the opposite of realistic; thus the Hellenistic portraits of Homer are treated as ideal when in the artistic sense they are more realistic than many actual portraits of earlier date.

${ }^{2}$ H.N. xxxiv. 71. I adopt M.1s. Strong's emendation of Alcman poeta for the Alcamen et and alchimena of the MSS.; if the name is

corrupt, the argument is unaffected.

${ }^{3}$ Anth. Pal xvi. 306-8.

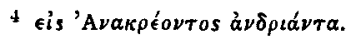

5 B.M.C. Jonia, Pl. XXX. 16; Arndt, Glyptothèque $N_{y}$-Carlsberg, text to Pl. 26-28.

${ }^{6}$ Bürchner, in Zeitschr. für Numismatik, ix. Pl. IV., 11 ; Viscouti, Icon. grecque, i. Pl. 3, 6; Jahn, Darst. Gr. Dicht. Pl. VIII. 8 ; Bernoulli, Münztaf. i. 15. 
J.H.S. VOL. XXXII. (1912), PL. V

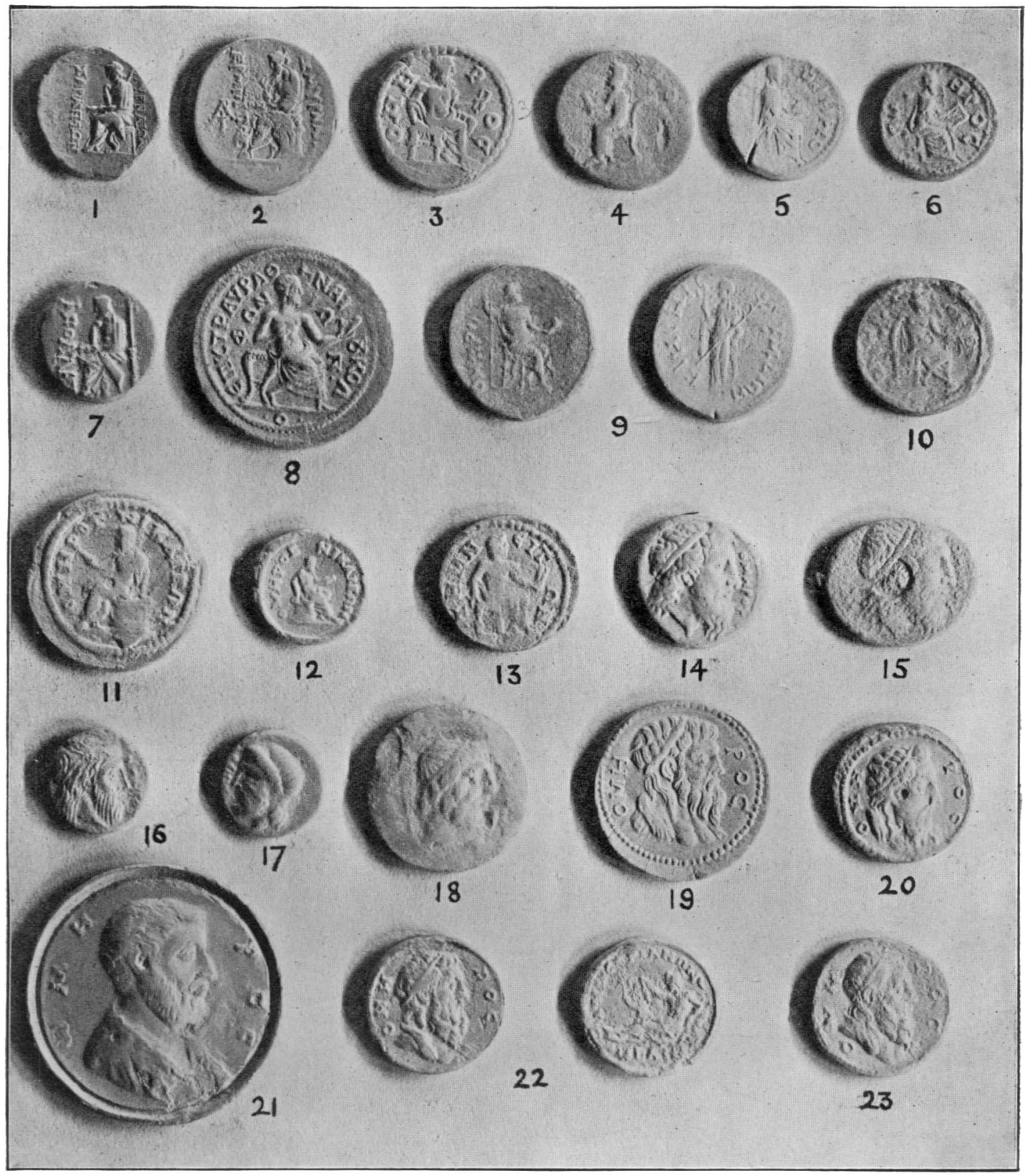

HOMERIC COIN TYPES. 
is in itsclf highly improbable; that they did not always do so may be safely asserted on the evidence of the coins and epigrams already alluded to. Leonidas and Eugenes describe a statue representing the poet as an old man, his garment trailing at his heels, one sandal on his wrinkled foot, tottering as he sings the praise of his loves; nothing could be further from the serene figure of the poet in the prime of life, with his chlamys cast round his shoulders and his firm and graceful posture, as we see him in the work of Cresilas; the stately draped figure on the coins is again entirely different. So too with portraits of Homer, and, though here artists had at least the traditions of age and blindness to guide them, even these are not always adopted. The serene and Zeus-like head on the coins of Ios has literally nothing but the fact of being bearded in common with the familiar Hellenistic type, so that the "acceptierter Formencharakter" of which Dr. Bernoulli, who believes that sculptors of ideal portraits worked within certain recognised traditions, writes in his invaluable Griechische Ikonographie (i. p. 18) can hardly be accepted as a formula by which to judge of these portraits. It is the special function of the class of coins with which we have to deal that they provide inscribed portraits which can be compared with the farriliar sculptural types, and which furnish independent and often datable evidence on the whole subject of ancient iconography.

It may be well to make clear at the outset the grounds on which a coin type can be regarded as a copy of a portrait.

(i.) The direct statements of ancient writers.

If we read that coins representing such a man were struck at such a place and can recognise the type on the coins of that place, their identification provides a basis for the identification of similar coin types elsewhere.

(ii.) The analogy of other monuments rerroduced on coins.

Here the Numismatic Commentary on Pausanias of Drs. Gardner and Imhoof-Blumer is invaluable, reproducing as it does over 700 coins and describing many others representing monuments and works of art, most of which are described or mentioned by Pausanias. Few of these are portraits, but the list includes the monuments of Themistocles and Miltiades and the famous group of Harmodios and Aristogeiton-the last curiously omitted hitherto in works on Greek Iconography, though, as I hope to shew in a future paper dealing with the coins, these famous statues are the earliest commemorative portraits we possess. In the great majority of portrait coins we have no Pausanias to aid us, but the analogy of these hundreds of other types is invaluable in dealing with the portrait class.

(iii.) The recurrence of types at different periods.

The types with which we are here dealing are very rarely the typical coins of the state; their occurrence, therefore, still more their recurrence, implies a strong local interest in a particular portrait. If the same type occurs sporadically, still more if it appears continuously, for three or four centuries, there is a strong presumption that it represents an actual 
monument. Indeed, the imperial issues of Greek cities, to which most of the coins of this class belong, are often so various that the reappearance of the same portrait type on them from time to time makes its monumental origin certain, and also renders it highly probable that the original work of art was in existence, or was at least familiar, when the latest of these was struck, since commemorative coins lose much of their point when the monument commemorated has disappeared.

\section{(iv.) The dates at which the coins are issued.}

Where commemorative coins occur, they usually belong to a time when the city is looking back on its past glories. This is especially true of Greek cities under Roman rule, which, though usually forced to adopt the imperial portrait as an obverse type, could yet use the reverse for the glorification of the city, its monuments and its great men. Commissions for such monuments, whether in honour of heroes or of citizens, became common after the middle of the fourth century: two of the most famous earlier examples occur on coins and one, if not both, in marble copies also, the Athenian Tyrannicides and the Themistocles on the coins of Magnesia ; both throw an interesting light on the subject of ideal portrait groups.

\section{(v.) Inscriptions.}

Where an inscription exists, the portrait so identified is placed beyond doubt; in spite of this it is usually said that these coin portraits have no value. If, however, the monument so identified was to mean anything to the citizens for whose use it was struck, it must have reproduced a familiar type.

(vi.) Character of the coin types.

Conflicting ideals of the same person are often found on the coins of the same city, and if the types are, as is usually the case, obviously earlier than the date at which the coins themselves are struck, there is a strong presumption, if not absolute proof, that these coins reproduce actual works of art. Successful archaising in widely different manners is not characteristic of local die-cutters of the Antonine period, so that the very want of artistic excellence in these later coins is an argument in favour of the genuinely early character of the types. Where again, as at Ios, we find an imperial bronze issue reproducing the type of a Homer found on late fourth-century coins side by side with a rarer issue representing a Homer with short hair of quite different style and unknown at an earlier date, we may be sure that only a different original can account for so unexpected a variation from the national type. Nor is there any difficulty in the supposition. Portraits of great men were common at Athens, yet we know of two statues of Sophocles, erected by Iophon and Lycurgus, and of two statues and one painting of Isocrates ; ${ }^{7}$ and Homer was almost the solitary glory of Ios. Again, at Smyrna and Colophon Homer is represented on Hellenistic coins with hair knotted 
behind over a fillet and one long lock falling on the neck, a style unknown at the period of the earliest of these coins, soon after 300 B.C., and persisting unaltered to imperial times; ${ }^{3}$ the statue therefore must have been earlier than the coins on which it is represented.

(vii.) Variations of position and details in the same figure.

Where the same figure is reproduced from a different point of view it is obvious that the artist is copying direct from the original and not from a previous coin type. The best example of this is to be found in the coins representing the Athena Parthenos, whose position varies so much that her shield is seen full-face, in profile, and from the inside, ${ }^{9}$ but instances occur on more than one portrait coin.

The scale of the coins is often too small for much detail to be perceptible, though the general character is usually clear. Heads hardly ever occur as reverse types, probably because they are less distinctive of the city which erected the monument in question; rarely even as obverse types, while fulllength figures are comparatively common, no doubt because they would be recognised at a glance. Where they do occur, their value is always high, but the only examples among ideal portraits are those of Homer, Sappho, Alcaeus, and Pittacus, the heads of Herodotus, Hippocrates, and others partaking of the character of historical portraits. It has been the misfortune of both classes of portrait coins, ideal and historical, other than those of rulers, to be slighted or neglected by recent writers on archaeology, while numismatists who have dealt with them have made no attempt to correlate them with other monuments. Before dealing with the coins of Homer therefore it may be well briefly to recapitulate the principal existing monuments other than numismatic, as well as the portraits recorded by ancient writers, that we may judge better what relation, if any, the large number of Homeric coin types bear to the portraits known from other sources.

\section{II.-Existing Portraits of Homer other than those on the coins.}

(i.) Minor monuments include the inscribed herm noted below (p. 304, No. xii) and a head, now apparently lost, which seems to have belonged to it; ${ }^{10}$ the relief dedicated by Archelaus of Priene now in the British Museum ; ${ }^{11}$ the relief in Paris representing Homer standing between figures of the Iliad and the Odyssey; ${ }^{11 a}$ the famous inscribed fragment in Berlin representing Homer reading from a scroll ${ }^{12}$ the statue with long hair given by Fulvius Ursinus (Imagines, p. 20) and other writers; the wall painting from Pompeii ${ }^{13}$; the questionable fragment from the South of France

8 The later bronze coins of this type are attributed in B.M.C. Ionia pp. 239 seqq. to the second and first centuries B.c. ; in Hist. Num. ${ }^{2}$ Dr. Head puts them among autonomous and quasi-imperial types (p. 593) quoting the famous passage of Strabo.

- Num. Comm. on Paus. Y. xviii-xxii.

${ }^{10}$ ef. Bernoulli, i. p. 5.
1I B.M.C. Sculpture iii. No. 2191, where literature.

11a Clarac, Mrusé du Louvre, Pl. 226.

12 Bernoulli, i. fig. 1; Inghirami, Gall. Omerica, I, Pl. IV.

${ }^{13}$ M.d.I. x. Pl. 35. 2. The figure of Homer appears to bederived from that on the Homereia of Smyrna. 
figured in Millin's Galérie Mythologique $:^{14}$ the much-injured figure on the mosaic of Monnus in Trèves $;^{15}$ the silver cup representing Homer, veiled and bearded, borne up to Olympus by an eagle ${ }^{16}$; and several gems. Of these the only one of importance is the inscribed jasper in Berlin which Furtwängler ascribes to later imperial times, ${ }^{17}$ and which recalls the statue in the Homereion at Smyrna, though the poet is, inexplicably, beardless, and is seated on a cippus in place of a stool ; the bust of 'Homer' on a sardonyx in Naples is, according to Bernoulli, a portrait of Epicurus to which the name of Homer has been fraudulently added; the cameo once belonging to Sir William Hamilton (Tischbein, Homer nach Antiken gezeichnet, Pl. II.) representing Homer seated with three of the Muses, that figured by Fulvius Ursinus (Imagines, p. 20), the beautiful beryl once in the collection of Lord Radnor, which, to judge from Worlidge's etching of it (No. 109 in his Cutalogue), followed the recognised Hellenistic type, and the long list in Tassie's Catalogue of Gems cannot safely be pronounced upon in the absence of the originals. ${ }^{17 \mathrm{a}}$ Finally the 'Homer' in relief which forms the frontispiece of the 1775 edition of Wood's Essay on the Writings and Genius of Homer is no other than the life-size medallion of Aeschines now at St. Petersburg.

(ii.) Apart from the examples of the familiar Hellenistic type recorded by Bernoulli, a type which is usually believed to be of Alexandrian origin, ${ }^{18}$ and the two statues to which the name is given (that at Naples has the head restored, and may or may not be a Homer; the other, with an attitude like that of the Lateran Sophocles and a head of the Hellenistic type is given by Tischbein, op. cit. ii. Pl. I.), three other 'Homer' types have been sometimes recognised, that now commonly known as the Old Sophocles, ${ }^{18 a}$ that usually called Epimenides, and the so-called Apollonius of Tyana. The first two attributions are very doubtful, as the first is almost certainly a Sophocles, and the only argument for the second, viz. that an artist of the close of the fifth century would, like Raphael in the cartoon of Elymas the sorcerer, represent blindness by closed eyes, is non-proven: the closed eyes are quite as likely to represent sleep, and as the work is almost certainly Attic, and the Athenians erected a seated statue of Epimenides in front of the

14 ii. Pl. CXXXI lis, No. 547 ; Jahn, Bilderchronik, p. 59.

${ }_{15}$ Ant. Denkm. i. Pl. 48, 11.

${ }^{16}$ Tischbein, op. cit. Pl. III. Inghirami, op. cit. i. PI. XVI.; Overbeck-Mall, Pompeii, p. 624. The 'Homers' of the reliefs in Welcker, A.D. Pl. 18 and 19 , have nothing to do with the poet, and I. de Bisschop's Homer (Icones signorum vetcrum, Pl. 71-2 ; Reinach, Répertoire, p. 570) is scarcely antique.

17 Bcschr. der geschn. Steine, No. 8683.

17a These last gems, like others in the above list, are not mentioned by Bernoulli.

18 These heads differ from each other in details, but are marked by a unity of conception and general character which makes it convenient to class them together here, with the exception of No. 5, which is a replica of the 'Old Sophocles.' cf. Bull. Comm. 1898, Pl. 3-4.

18a With which go the Arundel head in the British Museum, whose former name of Homtr has recently been again sugrgested ('angeblicher Homeroskof,') by Klein, Gesch. d. gr. Kunst. Vol. iii. p. 195 and Index ; and the relief of a seated poet, certainly the same person, in the Cabinet des Médailles, Annali 1841, Pl. L; Jahn, Bilıcrchron. ii. 4 ; Bernoulli i. p. 136. 
temple of Triptolemus (Paus. i. 14. 4), it is quite possible that this famous type is, as Visconti first suggested, a copy of that work. ${ }^{18 b}$ To the 'Apollonius' we shall return in connexion with the coins of Amastris. ${ }^{19}$

With the exception of the last, which is a doubtful Homer, none of these monuments is pre-Hellenistic; it is then to the coins that we must turn for information as to what the earlier Homeric type was like, and his head or figure appears on the coins of no fewer than eight Greek cities, a number quite unparalleled. ${ }^{20}$ The series is of extreme importance from the number of types and periods represented; it is noteworthy that, whereas most of the busts and reliefs represent the poet as bald, the pathos of age being, as we should expect of the Hellenistic period, added to that of blindness, none of the coins, as Dr. Bernoulli points out, so represent him. The coins range in date from $c .307$ B.c. to the third century after Christ, and, as already said, no portrait series can compare with this for number and variety of type ; but before dealing with them it may be useful to give a list of the portraits of Homer mentioned by ancient writers slightly fuller than that of Bernoulli and arranged as far as may be in chronological order.

\section{III.-Portraits of Homer mentioned by ancient writers.}

(i.) Not earlier than 467 or later than 460 B.C., the sculptor Dionysios of Argos placed portraits of Homer and Hesiod among the dedications of Micythos at Olympia. ${ }^{20 a}$

(ii.) A bronze statue reproduced on later coins (infra, p. 6) stood in the Homereion at Smyrna, which from the style must belong to a period not later, and perhaps earlier, than the beginning of the fourth century B C. ${ }^{21}$

(iii.) About 340 B.c. statues of Homer and another poet were placed on the grave of the poet Theodectes of Phaselis, on the Sacred Way; of these only the Homer survived in the time of the pseudo-Plutarch, ${ }^{22}$ who records elsewhere the inscription of the following statue.

(iv.) At Colophon was a statue of uncertain date whose inscription, recorded by the author of the Life of Homer above mentioned, also occurs in

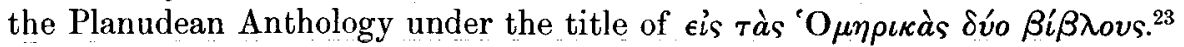

(v.) A bronze statue whose inscription, the very oracle given by Apolio

18b Dr. Bernoulli supports Visconti's attribution; for the Homer theory see Furtwängler, Beschr. der Münchn. Glyptothek. p. 298.

19 To the Homer types already mentioned may be added $\mathrm{a}$ bust at Wilton (Michaelis, Anc. Mar. p. 688) and a medallion head at Lowther Castle (ibid. p. 492), neither mentioned by Bernoulli; the writer has seen neither, and can only note that they are not described as modern by Michaelis.

${ }^{20}$ Bürchner (op. cit. p. 109) says ten, but this appears to include types assigned by earlier writers to Crete and other cities and now discredited. Bernoulli speaks of 'Smyrna, Kolophon, Chios, Nikaea, Kyme u. and.' as giving the full-length figure, Ios and Amastris as giving the head only. Temnos is in fact the only state omitted, but the different issues are not enumerated by Bernoulli, or apparently elsewhere.

20a Paus. v. 26. 2 : and Frazer's commentary.

${ }^{21}$ Strabo xiv, 646. The passage is quoted in full in note 32.

${ }_{22}$ Vit. X. Orat. 1socrates 10.

23 Anth. Gr. xvi. 292. 
to the poet, is recorded by Pausanias, stood in the vestibule of the temple at Delphi. ${ }^{24}$

(vi.) The Argives erected a bronze statue of Homer, whose inscription,

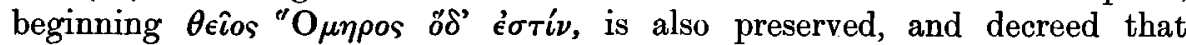
sacrifices should be offered to him daily and monthly and yearly, and that another sacrifice should be sent to Chios every five years. ${ }^{25}$

(vii.) Lucian mentions a statue with flowing hair that stood on the right of the temple of Ptolemy at Athens, to which he makes his poet offer prayers. ${ }^{26}$

(viii.) In the temple of the Ptolemies at Alexandria, of which we know nothing definite (cf. Pauly-Wissowa, s.v. Alexandreia, p. 1386), were the two following works of art: A statue of Homer, enthroned and surrounded by personifications of the cities that claimed to have given him birth. ${ }^{27}$

(ix.) A satirical picture of Galaton, representing Homer surrounded by a group of poetasters trying to catch his overflowings. ${ }^{28}$

(x.) A bronze statue with flowing hair stood, according to Christodorus, in the Zeuxippos at Constantinople. ${ }^{29}$ This statue is described at length by Cedrenus (quoted by Cuper, Apotheosis Homeri, 1737, p. 21).

- Statues or paintings are recorded or implied in the following passages (cf Pape, Griech. Eigennam. p. 1058):

(xi.) Anthologia Palatina, App. iii. 114; cf. Visconti, Icon. Gr. i. p. 27, note 1 .

(xii.) Anthologia Palatina, App. iii. 111-3. These three epigrams, sometimes ascribed to the sophist Aelian, are inscribed on a herm found outside the Porta Trigemina, and may have been originally written for the statue from which the herm was copied, not merely borrowed from a literary source and applied to the work of a sculptor. Fulvius Ursinus (Imagines, p. 20) held that the presence of these verses proved that Aelian had a villa on the Via Ostiensis, in the library of which stood this very herm.

(xiii.) It is highly probable from the context that there would be busts of Homer in the libraries built by Asinius Pollio and Atticus (Plin. N.H. xxxv. 10 : ef. Fulv. Ursinus, loc. cit.)

(xiv.) Finally, the basis of a standing bronze statue with a long metrical inscription was found in the sanctuary of Athena at Pergamon. ${ }^{29 a}$

24 Paus. x. 24, 2 ; pseud. Hdt., Vit. Hom.

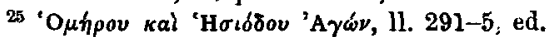
Teubner, 1908, p. 249; this composition, usually appended to the works of Hesiod, used to be attributed to a sophist of the age of Hadrian ; recently the recovery of a fragment from the Fayum (beginning at 1.63) dating from the third century B.c. proves that the text as we have it is a Hadrianic recension of a work of much earlier date, in fact, of the Movofiov of Alcidamas. (See Mahaffy, Flinders-Petrie Papyri, 1891, Pl. XXV. F. Nietzchc, Rhein. Mus. für Phil. 25, pp. 528 scqq; Acta Soc. Phil. Lips. ed. Ritschl. vol. i. 1870 ; T. W. Allen, Homeri Opera v. p. 225. The prose part of the work would appear to be of Hadrianic date, i.e. of the period to which the earliest Chian issues bearing the portrait of Homer can be assigned (post, pp. 7-8); there is therefore no clue to the earlier date limit of the statue or of the Argive decree as to the fiveyearly embassy to Chios; but the author of the 'A $\gamma$ '́n speaks of it as a well-known fact, and his statement as to the Argive sacrifices agrees with that of Aelian, V.H. ix. 15.

${ }_{26}$ Enc. Dem. 2.

27 Ael. V.H. xiii. $22 . \quad 28$ Ibid.

a Anth. Pal. ii. 320 seqq. Homer is described as bald about the forehead, but with long hair falling on his neck.

29a Fränkel, Inschr. von Pergamon, i. No. 203. 
It is worthy of notice that we find two authors, the art critic Lucian as well as the rhetorician Christodorus, expressly mentioning a type of Homer

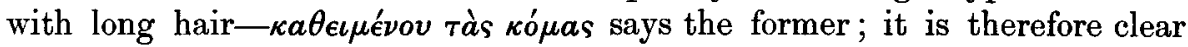
that long hair was not a usual feature of Homeric portraits, and this is confirmed by the coins and monuments (cf. p. 319, infra). Which, if any, of the above statues it was that Zoilus flogged Lucian (Imagg. 24) unfortunately does not tell us.

\section{IV.-Coins bearing the portrait of Homer.}

The list of cities which struck coins in the poet's honour does not, curiously enough, coincide with the list of cities which claimed to give him birth in any variant of the famous hexameter

Smyrna, Rhodus, Colophon, Salamis, Chios, Argos, Athenae.

They are, as already mentioned, Smyrna, Chios, Colophon, Cyme, Nicaea, Temnos, Ios; and Amastris, but others may still come to light, as one or two of the coins are of extreme rarity, existing sometimes in single specimens. M. Fustel de Coulanges' statement ${ }^{29 b}$ that "C'était l'usage dans les anciennes cités grecques amoureuses de la gloire littéraire autant qu'envieuses de toute autre, de représenter des poètes sur leurs monnaies" is, unfortunately for our knowledge of iconography, an overstatement. We have Homer, Sappho, Alcaeus, Anacreon, Stesichorus, and among dramatists possibly Philemon, on the coins of their respective cities, but they are a small proportion even of the Greek poets whose works still survive and who were honoured, by statues or otherwise, in their native cities. The coins of Homer may be divided into two classes, those bearing seated figures, comprising all the issues of the first six states, and those with the head only, comprising all the issues of the two last.

\section{I.-Full-length Figures.}

(i) Smyrna.

The Homeric claims of Smyrna are discussed at length in Leo Allatius, de patria Homeri, c. $\mathrm{xii}^{30}$; they were very strong, as the familiarity of the name Melesigenes, given to him after his reputed father the river-god Meles sufficiently shows, and they were upheld not only locally, but by the mothercity Athens, who thereby made good her claim to count Homer as in some sort a citizen of her own. Smyrna could not only show the river Meles, and the cave on its banks in which he had composed his works, but a strong body of literary tradition also ; Smyrnaei vero suum esse confirmant,

29b Mémoire sur l'île de Chio, in Questions Historiques, edited by M. Camille Jullian, 1893 , p. 313.

30 For this and all other cities claiming Homer as a citizen the references in Pape, Gr. Eigennamen, s.v. Homeros ; Slaars Etude sur Smyrne, 1868 ; the standard work of Westermann, Vitae Script. Graec. Minores; the Life printed in Iriarte, Regiae Biblioth. Matritens. Codd. Gr. 1769 , p. 233, and vol. v. of Mr. T. W. Allen's Oxford Homer should be consulted. 
as Cicero writes, and their coins vindicated this claim from the earliest period of Smyrna's entire independence.

The coins are as follows:

a. R. 75 and $\mathbb{E}$. $\cdot 75-1 \cdot 0$. Second century B.C. to imperial times. [PI. V., 1 and 2.]

Obv. Laureate head of Apollo r.

Rev. Homer seated 1. on cushioned stool with lion fore-feet, a staff or sceptre ending in a flower at his side, $r$. hand open supporting chin, l. lying on knees holding closed scroll; 1 . foot forward, $r$. drawn back, himation passing under $r$. and over l. shoulder; hair rolled over fillet and knotted on neck, with a long lock falling to the shoulder. $\Sigma M Y P N A I \Omega N$. Magistrate's name. ${ }^{31}$

This important series, which varies only in the most trifling details, unquestionably reproduces the bronze statue in the Homereion at Smyrna of which we hear from Strabo and Cicero ${ }^{32}$; the statement of the former that the bronze coins were called Homereia from this statue need not be pressed, as these issues were incomparably commoner than the earlier silver types: the name is the really interesting point. The statue is represented in such detail, notably on the finer specimens of the bronze issues, that it can be approximately dated to the end of the fifth or at latest the beginning of the fourth century B.c., after which hair knotted on the nape of the neck and the long side lock ceased to be used in portraits until the archaistic revival later than the date of the earliest Homereia, if not of Smyrna, at least of the similar type at Colophon (p.310,post). A close numismatic parallel is the head of the Dionysos of Alcamenes on late bronze coins of Athens.33 The general effect-indeed the whole conception-is that of a cultus statue of the great age; the scroll is a mere attribute, not a motive; as in late statues; and this coin is probably our earliest artistic evidence as to the cultus type of Homer. The next type is very different.

B. $A$. 8 or 85 : late second or early third century after Christ. [Pl. V., 3.]

Obv. OMHPOC. Homer seated r. on stool with decorated legs, wearing himation cast across knees and over r. arm, which rests on stool; in l. hand, which is raised, a scroll halfunrolled.

Rev. CMYPNAI $\Omega \mathrm{N}$ within oak-wreath. ${ }^{34}$

\footnotetext{
31 B.M.C. Ionia, pp. 238, 244-7 ; Bernoulli, Münzt. i. 6 ; Macdonald, Hunter. Cat. ii. p. 359.

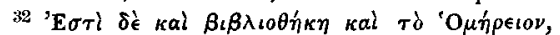

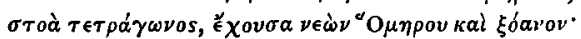

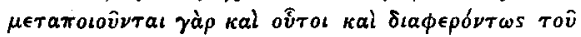

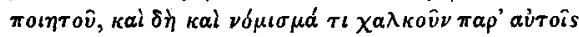

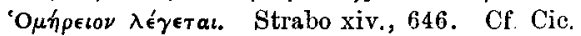
Arch. 8, Homerum Colophonii civem esse dicunt suum, Chii sunm vindicant, Salaminii scpeliunt,

Smyrnaci vero suam csse confirmant itaque ctiam delubrum eius in oppido dedicaverunt. 3i Num. Comm. on Paus. Pl. CC 5.

${ }^{34}$ B.M.C. Ionia, p. 262 ; Macdonald, Hunter. Coll. ii. p. 374. The type is inaccurately figured by Cuper, Apotheosis Homeri, p. 23, where Homer is describel as holding calamum rel palmam, ut ridetur ; cf. Gronovius, Thes. ii. p. 19.
} 
Smyrna $\beta$ is obviously derived from a different original of later date than $a$; the hair is no longer knotted in archaic fashion over a fillet; the scroll is unrolled and held out, not laid attribute-fashion on the knee; the right hand no longer supports the poet's chin, but rests on the stool at his side. The conception in short has changed; from Olympian calm the poet has passed to very human authorship; and the change alone would mark the work as of later date. It is probable that the original statue, which appeared on the coinage of Smyrna from the third century to imperial times and gave its name to it, was longer in existence when this second and unfamiliar type was issued; the probability is that it had been destroyed and replaced between the visit of Strabo and the age of the later Antonines to which $\beta$ belongs. If this is the case, it must have been this second statue which was seen by the traveller and historian Coriolano Cippico in $1472 ;{ }^{34 a}$ if, however $\beta$ represents a statue erected elsewhere in Smyrna, Cippico may have seen the very statue recorded on $a$; the 'monument' would be in either case the famous Homereion. Whether this was identical with the building destroyed in 1702 and called either the Homereion or (from a double herm found in its ruins) the temple of Janus must remain uncertain. The latter building is discussed by Slaars (Etude sur Smyrne, p. 71), but without reference to the interesting, and except as to the actual position of the Homereion explicit, statement of Cippico.

\section{(ii.) Chios.}

For the Homeric claims of Chios the Hymn to Apollo, Thucydides, and Aristotle (Rhet. II. c. xxiii) all vouch ; these and other passages are collected and the claims of the island urged by the Chians Leo Allatius (c. xiii) and Adamantios Korais ("A we know the title of a book by Hypermenes, $\pi \epsilon \rho i$ Xíov 'O $\mu$ ýpov (Westermann,

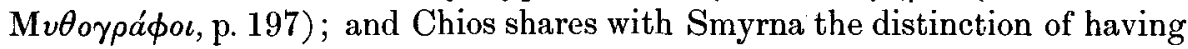

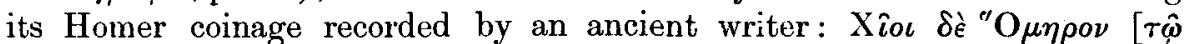

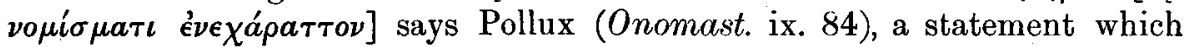
Allatius rashly enlarges (p. 231) into apud Chios aenea moneta fuit, cui nomen Homerus, as if the coinage in this also was an exact parallel to the Homereia of Smyrna. There appear to be at least three issues of very different date, although all have hitherto been indiscriminately assigned to the third century of our era.

a. A. 8. Early second century after Christ? [P]. V., 4.]

Obv. Straight-winged Sphinx seated 1. on club (?) placing r. forepaw on amphora; border of dots.

Rev. OM[HPOC] XIOC. Homer seated 1. on high-backed chair holding scroll in 1 . hand; $r$. hand not seen..$^{35}$

\footnotetext{
ita Itaque urbs antiqua varia fortuna ac multis monumentis insignis horarum spatio in cineres collrpsa est (when the Venetians fired it). Hic ridimus multa antiqua monumenta quadrati lipides ac marmore magnifice acdificate, quorum nonnulla corruerant quaedam etiam extabant. Inter quae Honeri monumentum cum statua et
}

inscriptione graecis litleris. This passage, from Cor. Cepionis Dalmatae de Petri Mocenici Imperatoris gestis libri tres, Venice 1477, sig. c 3 , does not ajpear to have been kitherto connerted with the Homertion.

is B.M.C. Ionia, p. 346. The date is suggested on p. 343. 
B. $\quad$ E. 7. Probably later Antonine. [Pl. V., 5.]

Obv. $\mathrm{N} \Omega \mid \mathrm{X}$. Sphinx with straight wings seated l. with paw on prow.

Rev. JO१HMO. Homer of finer style seated r., both hands holding open scroll ; the same figure as $a$, but seen to r., so that both hands are visible. ${ }^{36}$

$\gamma$. A. 65. Age of Gallienus. [Pl. V., 6.]

Obv. $\mathrm{X} I \Omega$ N. Sphinx with curved wings seated l. with symbols; border of dots. (T'wo varieties, with paw raised or laid on amphora.)

Rev. OMHPOC. Homer seated $\mathrm{r}$. as $\beta$ on chair unrolling with both hands a scroll which is sometimes blank (as in B.M. specimens), sometimes inscribed with an $A$ (Bernoulli, Münzt. i. 8), sometimes with the word IAIAC (Eckhel, Syll. iv. 7; Whitte, de rebus Chiorum, p. 105). ${ }^{37}$

The arrangement of the three different issues above adopted first calls for comment. The British Museum specimens of $a$ and $y$ are classed as 'Time of Gallienus?' without regard to the difference of style between $a$ and $\gamma$; but Pollux' statement makes it certain that coins bearing the portrait of Homer were struck under the Antonines, and stylistically it is difficult to assign $a$ to a late period, though the exacter date adopted here is based on the evidence of the inscription, which is as follows:

$X I O \Sigma$ or $X I O C$ is found on all Chian coins from before 350 B.C. (B.M.C. Ionia, Chios No. 40) to the end of the bronze coinage with archons' names of early imperial times. Next comes a rare issue of obols and dichalka not much later in date than the above, with the form $X I \Omega N$ and without archons' names (B.M.O. 113-4; Hunter. Coll. : Chios, Nos. 52-3) and henceforth the form XIOE or XIOC never re-appears. Our type a, however, has the form XIOC, and would therefore be contemporary with the bronze coinage with archons' names of early imperial times; therefore it is probably one of the coins referred to by Pollux.

$\beta$, a type to which Mr. Mavrogordato called my attention, and which I reproduce from the specimen in his collection, reads outwards and thereby connects itself with the large 3-assaria issues, on which the same type of straight-winged sphinx, and the same symbol, the prow, also occur (B.M.C. 122-5 ; Hunter. Coll. ii. Pl. LIII.); these pieces are assigned to the period of the Antonines, therefore the date of the similar Homer issues is probably the same.

\footnotetext{
${ }^{36}$ Collection of Mr. J. Mavrogordato; Macdonald, Hunter. Coll. ii. Chios, Nos. 67-8 ; Gronovius, Thes. ii. p. 19.

${ }_{37}$ B.M.C. Ionia, p. 346, Nos. 140-1 ; Fulv. Ursinus, Imagines p. 20 ; Leo Allatius de patria Homeri, p. 11 ; Cuper, Apotheos. Hom. p. 23 : apparently also reproduced in the last of Grono.
}

vius' engravings (Thes. ii. p. 19). It should be noted that Whitte in the work cited above men. tions a second specimen of $\gamma$ with $I \Lambda I A C$ inscribed as in the Hunterian Collection. The inseription is not mentioned in connexion with any of the specimens figured in the Hunterian Catalogue. 
$\gamma$ is obviously of very late date, well on in the third century after Christ; probably, as is usually said, it belongs to the age of Gallienus. The weights of all three roughly correspond with the ordinary issues with which they are here connected : I say 'ordinary,' because all three issues are distinguished not only by the type of Homer, but by the entire absence of any mark of value, a feature peculiar to themselves. Whether these coins were issued for special occasions is a matter for conjecture, but it seems at least possible.

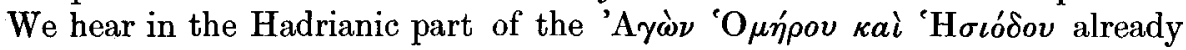
mentioned of the Argives' five-yearly embassy to Chios with $\theta v \sigma i a \iota$, and the coins might easily be struck in connexion with what must have been a famous festival; on the other hand, Pollux mentions the Chian coins of Homer along with others, such as those of Mytilene and Argos, in which the types are the ordinary currency of the state. The question must at present remain open.

The Chian type itself is clearly sculptural, nor does the contradiction implied in the blind poet reading from the inscribed scroll, familiar also in the Archelaus relief in the British Museum and that at Berlin, appear to have disturbed the artist. The poet is seated, holding a written scroll with both hands, on the throne appropriate to a god, and if this conception of Homer as the author not only holding but actually reading his own works is a late one, the statue, especially as we see it in $\beta$, is of considerable dignity and follows a good tradition. This is the only numismatic example of the reading type, which can hardly have arisen before the Hellenistic age; it is therefore probable that in Chios itself an earlier statue existed, which was replaced, in popular favour at least, not earlier than the Hellenistic age by that reproduced on the coins; it is inconceivable that the traditional home of the poet, the actual home of the Homeridae, the state which celebrated its connexion with the poet by a festival every five years, to which a state so remote as Argos sent a solemn embassy, in which at the present day the name of Homer is a household word and a source of pride, ${ }^{38}$ would be until Hellenistic times without a statue of Homer himself.

The Homeric coins of Chios are then of unusual interest, both archaeological and numismatic, and are especially valuable as illustrating every one of the reasons already given for believing in the authenticity of these coin portraits. We have the direct statement of Pollux that coins with the portrait of Homer were struck at Chios; the same type recurs on different issues; the dates and absence of marks of value point to a distinctly archaeological intention on the part of the state; the inscription OMHPOC identifies them; their artistic character is that of an earlier age than the date of the earliest of the coins; finally, the figure is represented from two points of view, and correctly represented, the left arm being held higher than the right, and therefore seen alone when the statue is represented from the left, as it is on $a$, when the scroll is not so visible to the spectator.

${ }^{38}$ Fustel de Coulanges, Chio, in Questions Hictoriques, edited by Catmille Jullian, 1893, pp. 315 scqq.

H.S.-VOL. XXXII 
It is something to have recovered the order of these Chian issues, and if too much has been said of the five-yearly festival of which we know so little, it is in the hope of saving others the difficulty experienced by the writer in tracing the statement at all, accident only having suggested the 'A $\gamma \omega$ ' $\nu$ after years of useless search on the strength of reference-less allusions to the festival in various Dictionaries of Antiquities.

\section{(iii.) Colophon.}

The literary claims of Colophon were based primarily on the Margites, which were made the most of by patriotic Colophonians like Hermesianax. The story was, however, widely received, as the references in Cicero (quoted above $\grave{a}$ propos of Smyrna) and the Palatine Anthology (ix. 213 ; xvi. 292, etc.) sufficiently show. ${ }^{39}$ The coins are of some interest, and vary greatly in date.

a. Æ. 7. After c. 300 and before 189 B.C. [Pl. V. 7.]

Obs. KO^O $\varnothing \Omega N I \Omega N$. Apollo Citharoedus advancing r. and holding lyre and patera.

Rev. Homer seated l. on high-backed chair, leaning his head on $\mathrm{r}$. hand; in l. hand a scroll. AחO $\wedge A \Sigma{ }^{40}$

But for the throne in place of a stool and the absence of a staff, the type is identical with that on the Homereia of Smyrna, and it is quite possible that the Colophon type may actually be derived from a copy of the famous statue in the former city, which, as we have seen, probably belongs to the end of the fifth century B.c.

B. A. 1·1. Third century after Christ. Otacilia.

Obv. $\cdot M \cdot \Omega$ TAK - [EBHPA. Bust of Otacilia $r$.

Rev. $\operatorname{KO} \wedge \circ \varnothing \Omega \mathrm{N} I \Omega N$. Homer seated $\mathrm{r}$. on stool, himation cast round lower limbs, r. foot drawn back, r. hand slightly raised, l. extended holding open scroll on which A (?) is written (cf. Chios $\gamma)^{41}$

This type differs completely from the last, and is a bold and pictorial attempt to represent a statue seen three-quarter face from the front. The date of the original is obviously later than $a$.

$\gamma$. A. 1.15. Volusianus. [Pl. V. 8.]

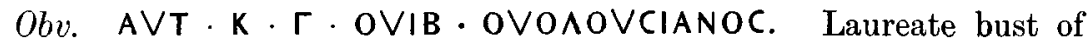
Volusian r. wearing cuirass and paludamentum.

Rev. EMICTP AVP AE HNAI $\varnothing$ KOAO $\phi \Omega N I \Omega N$. Homer seated r. on stool, himation cast round lower limbs, r. foot drawn back, $r$. hand slightly raised, 1. extended holding open scroll. ${ }^{42}$

\footnotetext{
39 Cf. Leo Allatius, c. ix. and Westermann, Vit. Script. Graec. Min. p. 28.

to B.Af.C. Ionia, p. 41; Hunt. Cat. ii. p. 325. A variant of this type reads

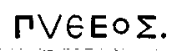

41 İbid. p. 44.

42 Ibid. p. 45. This specimen is countermarked $\mathbf{B}$.
} 
ס. A. 1.05. Valerianus.

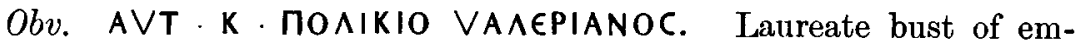
peror $r$. wearing cuirass and paludamentum.

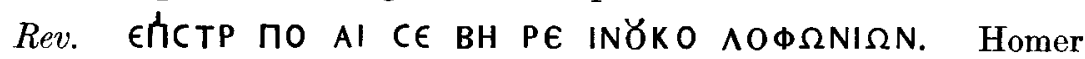
seated as on $\beta$ and $\gamma^{43}$

These three clearly reproduce the same original, though the stool on which the poet is seated varies on each specimen; on $\beta$ it is of the curule order, on $\gamma$-by far the finest and best preserved-it has curved legs ending in lions' feet (?) at the four corners, on $\delta$ the general form agrees with $\beta$, but the legs are straighter. The hair and beard, best seen on $\beta$, are short, and there appears to be no suggestion of decrepitude in pose or figure. Its appearance in place of the much earlier type of the Hellenistic coins on coins of the third century after Christ after an interval of some five centuries suggests (a) that the first or Smyrnaean type was no longer in existence, (b) that the cult of Homer in Colophon had attained some new development between the years 244, the accession of Otacilia, and 260, the death of Valerian, since it is thus emphasised on their coinage.

(iv.) Cyme.

The Homeric claims of Cyme, in the older books always referred to as Cumae, are described in the pseudo-Herodotean Life (cf. Leo Allatius, c. viii.) and were strongly urged by Ephorus, himself a native of the city; ef. also Anth. Pal. xvi. Nos. 293-9.

a. E. 9-85. Period of the Early Antonines. [Pl. V. 9.]

Obv. OMHPOC. Homer seated r. on stool, holding sceptre ('hasta pura,' Mionnet) and scroll wearing himation cast round lower limbs and over r. shoulder.

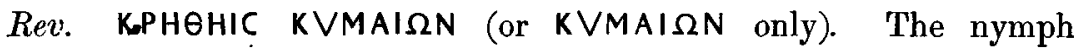
Critheis, mother of Homer, standing to l. clad in chiton and himation and holding out veil in $r$. hand; in 1 . transverse sceptre. ${ }^{44}$

B. A. 8 Time of Septimius Severus and his family. [Pl. V. 10.]

Obv. OMHPOC. Homer seated $\mathbf{r}$. on stool, himation cast round lower limbs and brought over r. arm; r. hand rests on seat, 1. extended holds scroll ; r. leg drawn back; hair knotted on neck.

43 Ibid. p. 46.

4 Imhoof-Blumer, Nymphen u. Chariten, Pl. X. 8, and No. 436, Mionnet, Suppl vi. p. 15, No. 119 . A poorer specimen, $A . \cdot 95$, has recently been acquired by the British Museum, with the figure of Critheis turned more to the 1 . I have to thank Dr. Regling for the cast here reproduced. The Critheis of Gronovius (Thes. ii. p. 12) is a purely gratuitious attribution. For Critheis see Philostratus, Imagg. ii. 8. 


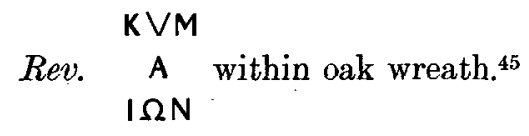

This type of Homer exactly resembles that on the coins of Nicaea (infra, p. 11.) except that on these the stool is replaced by a solid circular seat; both obverse and reverse are identical with Smyrna $\beta$, except that, according to the British Museum Catalogues, the faces are reversed; the last is given to about the same date, that of Nicaea belongs to the time of Commodus. The significance of the group will be discussed later.

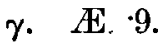

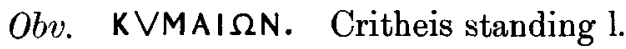

Rev. EחI $\Sigma$ TP. ПANO. Homer seated as on $\beta .45 a$

If Cyme $\beta$ belongs to a series of coins struck by a group of cities (see infra, p. xx.), Cyme $a$ is clearly a local and purely commemorative issue; both obverse and reverse types are associated with Homer, so that the coins can hardly have been of imperial significance. Critheis was commonly said to have been a native of Cyme, hence her appearance on the coin; $\gamma$ combines the Critheis of $a$ with the Homer of $\beta$, but is nearer in date to the latter.

\section{(v.) Nicaea.}

There appears to be no evidence to connect Homer with Nicaea, but an important series of Homer coins was issued in the reign of Commodus.

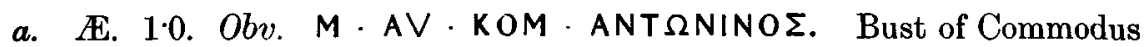
r. bare-headed.

Rev. OMHPOL NIKAIE $\Omega$ N. Homer seated 1. on circular seat (or cippus?), wearing himation over both shoulders and knees, leaving torso bare; l. hand rests on seat, $r$. is extended, holding scroll ; l. leg advanced, r. drawn back. ${ }^{46}$ [Pl. V. 11.]

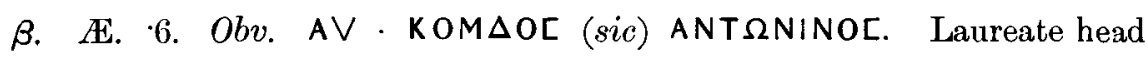
of Commodus $r$.

Rev. OMHPOC NIKAIE $\Omega$ N. Homer seated r. as above, but type reversed, 1. hand holding scroll and $r$. on seat. ${ }^{47}$ [Pl. V. 12.]

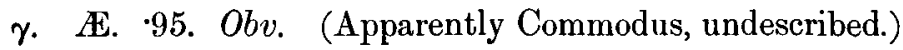

Rev. OMHPOC NIKAIE $\Omega$ N. Homer l. as $a$; ends of fillet clearly seen on neck and details of drapery clearer than $a$, which is of broader and coarser style. ${ }^{47 a}$

45 B.M.C. Troas, p. 115 ; ef. Borrell, N.C. vii. p. 47 ; the form of the seat is somewhat obseure, and was described by Morelli (Spec. Rei Numm. 'Tab. iv.) as rocks.

45a Mionnet, iii. 9, 50, who describes the figure as that of a plilosopher.

$\$ 6$ Waddington, Recucil, Pl. LXXIV. 23.

47 Ibid. PI. LXXIV. 24 ; Gronovius, Thes.

ii. p. 19.

tia Bernoulli, Münzt. i. 7. 
These coins represent a type allied to that of Temnos and other cities but distinguished by the type of seat and other details from the Homer of these latter coins; the group will be discussed when the one Homer issue of Temnos has been described.

(vi.) Temnos.

Æ. $\cdot 8, \cdot 75$. Third century after Christ. [Pl. V. 13.]

Obv. SEYC AKPAIOC. Bust of Zeus Acraeus r.

Rev. THMNEIT $\Omega$ N. Homer seated r. on stool, l. hand extended holding scroll partly unrolled, $r$. hand resting on seat beside him ; r. foot forward, l. foot drawn back; fillet round hair; himation cast about r. arm and lower limbs. ${ }^{48}$

This type belongs to the group already mentioned, but the specimen in the British Museum is of better style than most. The group consists of Smyrna $\beta$, Cyme $\beta$ and $\gamma$, Nicaea $a$ and $\beta$, and Temnos $a$, and as Borrell long ago suggested, ${ }^{44}$ may have been struck to commemorate some particular festival celebrated in honour of Homer in the cities in question. Smyrna $\beta$ and Cyme $a$ have precisely the same type on the other side also, the name of the city within an oak-wreatb; all but two, those of Temnos and Cyme, bear the name of Homer. The forms OMHPOC IMYPNAI $\Omega N$, NIK AIE $\Omega N$, etc. recall the famous coin of the latter city bearing as reverse type a statue of Alexander the Great and the inscription $A \wedge E \equiv A N \triangle P O N$ NIK AIEIC; ${ }^{49}$ judging from this type alone it would seem probable that the figure of Homer was a reproduction of a statue. Further, a type common to several cities must have been both famous and familiar, yet the variation in detail is such as to make it improbable that the original was a purely numismatic type. The seat of Homer is at Nicaea a round and solid base resembling a cippus; at Cyme, Smyrna, and Temnos it is a square stool ; the drapery hangs over the stool in the coins of Cyme, but not in those of Nicaea and Smyrna; the hand holding the scroll also varies, in accordance with the common practice of die-cutters. If then the coin types represent a sculptural type, is it probable that there was more than one original ? The answer must, I think, be in the affirmative, though it is in a high degree probable that all were ultimately derived from a common original of earlier date. Were one type agreed upon by the cities of Smyrna, Nicaea, Cyme and Temnos for a common festival during the Antonine period-probably the reign of Commodus, since the Nicaean coins, the only ones bearing an imperial portrait, are of that date-such variations in the seat of Homer and the drapery would be improbable. If, however, the suggestion here made as to a common date for this group of coins is accepted, it would necessitate a revision of the dates above assigned, in accordance with the British Museum Catalogues, to Smyrna $\beta$ and Cyme $\beta$ and $\gamma$, and this seems stylistically probable. It is, however, possible that 
one single statue was the direct model for all the coins, as the Olympian Zeus was ultimately the model for the countless varieties of Alexandrine tetradrachms, and that variations in the coins were introduced locally. That the types are either immediately or ultimately based on a sculptural type or types there can be no doubt whatever.

This completes the list of Homeric figure types on coins : before passing to those with the head only, one or two points must be mentioned.

Two of the types, Smyrna $a$ and Colophon $a$, are very early for coins of this class, both belonging to the third century B.c. and both obviously reproducing a work or works of still earlier date. That at Colophon may well have been based on the famous statue at Smyrna, but in any case the type appears to belong to the fifth century B.c.; the Homereion at Smyrna therefore was not of later date. If then the cult of Homer were established in the fifth century, the cultus type of Homer would in some degree partake of the character of a fifth-century god, and would therefore be very different from the later realistic ideals. What one such type was like these coins of Smyrna and Colophon prove: the poet is seated lost in thought, his scroll, which is treated as a mere accessory, resting on his knee; his bent head rests on his right hand, his staff is beside him. Next in date apparently comes the noble type on Cyme $a$, which is based line for line on the Pheidian Zeus, with the scroll substituted for the Victory and a stool for the throne. In both these types Homer is the god, not merely the poet or the blind old man of Chios. In the second stage represented on the coins the poet is further removed from the divine calm; the scroll no longer rests on his knee, but is held out as if the poet were about to read; the audience is remembered, the Olympian calm is gone, yet even here the poet retains the half-draped dignity of a Zeus, nor on any coin type do we find an approximation to the realism of the poet-statue in the Naples Museum - whether Homer or not-with its every-day garb. ${ }^{50}$ In the third and latest type Homer, although he holds the scroll in both hands, appears as the author, not as the god, but the dignity of pose and drapery is otherwise retained; this third type is only found on the coins of Chios. Homer is still o $\theta$ cós, as he is frequently termed in the Anthology, ${ }^{50 a}$ though the motive is changed, and we may fairly say even of this later conception that along with the Hellenistic conception of the reading Homer is preserved much of the character of the earlier types with the scroll as attribute, not motive, as we know them on the coins of Smyrna, Cyme, and the rest.

The existence of more than one type in the same city has been already explained; at Smyrna the famous statue was probably destroyed, or a second type would hardly have appeared on the coins; elsewhere more than one type may have existed, or a statue or replica of a statue have been reproduced on the coins of different cities issued at one time for a common purpose. The Homereia of Smyrna are universally recognised as reproducing the statue in the Homereion, and this statue or its successor was seen by a 
fifteenth-century traveller; if then these coins are not isolated examples, but only types of other coins bearing commemorative portraits, it follows that the other coins, for which there is no such literary evidence, also reproduce statues. They are therefore the corner-stone of Greek iconography, other than that of rulers, from the numismatic point of view.

How far the evidence here presented applies to the coins of the two states which issued coins bearing the head of Homer must now be considered.

(vii.) $1 o s$.

The claims of Ios were supported by Apollo, ${ }^{51}$ and the statue of Homer at Delphi already referred to was inscribed with the oracle given to him (Paus. $x$. 24. 2), but even this does not convert Pausanias, who 'will give no opinion as to the country or date of Homer.' That Homer was buried at Ios was, however, very generally believed, and his grave was shown down to a late date. The coins range in date from the end of the fourth century B.c. to imperial times.

a. A. didrachm. c. 307 B.C. or earlier (time of Alexander, according to Friedländer, $Z . f . N$. i. p. 294). [Pl. V. 14.]

$O b v$. OMHPOY. Head of Homer r. wearing fillet, the ends of which are visible.

Rev. IHT $\Omega \mathrm{N}$ within laurel wreath..$^{52}$

B. AR. Drachm.

Obv. OMHPOY. Head of Homer as above.

Rev. IHT $\Omega \mathrm{N}$ as above.

Both of fine style..$^{52}$

E. 85-6. Fourth-first centuries B.c.

Some of these coins are of fine style, certainly contemporary with $a$ and $\beta$; others (e.g. B.M.C. 3 and 4) are very inferior, perhaps even of Roman date.

\%. Æ. 6. Fourth or third century B.c.

Obv. OMHPOY. Head of Homer as above; countermark, head of Helios r. [PI. V. 15.]

Rev. IHT $\Omega$ N. Pallas r. hurling spear; in l. hand shield; before her a palm-tree. ${ }^{53}$

\footnotetext{
51 Further evidence is collected by Leo Allatius, c. xi.

52 Head, Hist. Num². p. 486. B.H. Cat. Crete, etc. Introd. p. xlix. The only known
}

specimen of the didrachm is at Berlin, and I have to thank Dr. Regling for sending me a east.

53 B.M.C. Crete etc. p. 101, 1. 


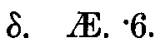

Obv. OMHPOY. Head of Homer as above, but of inferior style; no countermark. [Pl. V. 16.]

Rev. Pallas r. as $\gamma^{54}$

є. 2.65 .

Obv. OMHPOY. Head of Homer as above, but l, of fine style, not early as $a$; the same type is also found with head to $r$. [PI. V. 17.]

Rev. I HT. Palm-tree. ${ }^{54}$

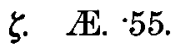

Obv. OMHPOY. Head of Homer $\mathbf{r}$.

Rev. I HT. Palm-tree, as above. ${ }^{54}$

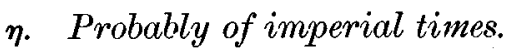

स. 95 .

Obv. Head of Homer r., short hair, wearing fillet without ends; border of dots. [Plate V. 18.]

Rev. IH $\mathrm{T} \Omega$ N. Pallas, as on $\gamma^{55}$

$\theta$. $\mathrm{E} .75$.

Obv. OMHPO Y. Similar head r., border of dots.

Rev. IH $\mathrm{T} \Omega \mathrm{N}$. Pallas standing l. holding patera over lighted altar and spear; behind her, shield..$^{55}$

The Homeric coins of Ios fall, it will be seen, into two well-marked classes, $a-\zeta$ and $\eta-\theta$. The first represents a type very different from the recognised Homer, a bearded man of serene aspect with flowing hair, deepset eyes and placid features, who, but for the inscription, would be identified as Zeus or Asclepios; its nearest parallel in art is in fact the Asclepios of Melos in the British Museum. This is by far the earliest ideal portrait head identified by an inscription found on Greek coins, and the type of Homer represented appears to belong to the first half of the fourth century B.c., distinctly earlier, that is, than the date of the coin, which is of the Rhodian standard. From its constant appearance on the coins of Ios down to Roman times it may be assumed to represent the type of the poet most familiar in Ios, possibly the head of the statue that must have existed in the sanctuary where his grave was shown, though a reproduction of an existing nonument would at this date be unusual. ${ }^{56}$ The genitive OMHPOY is hardly

${ }^{54}$ Ibid. Nos. 4, 6, 7.

${ }_{55}$ Ibid. p. 102 ; Hunter. Coll. ii. p. 205.

${ }^{56}$ I may perhaps quote Plutarch's picturesque remark about Smyrna and Ios at the beginning of his Life of Sertorius, that "of two cities which take their name from the two most agreeable odoriferous plants, Ios and Smyrna, the one from a violet the other from myrrh, the poet Homer is reporte 1 to have been born in one, and to have died in the other." 
surprising; the nominative is more usual on coins; but we have already quoted the $A \wedge E \equiv A N \triangle P O N$ of Nicaea, and may now quote the $\Lambda E \Sigma B W N A K T A$ QI $\triangle O \Sigma O \phi O N$ of Mytilene as parallels, if not precisely similar examples, while the genitive itself is found on certain herms.

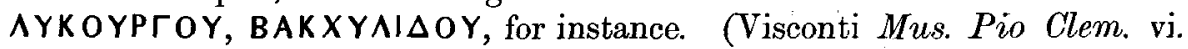
p. 142, note 1.)

Setting aside the coins of Smyrna and Colophon as too small in scale to furnish much stylistic detail, this then is the earliest known portrait of Homer, and its date-about the close of the fourth century B.C.-atfords a starting-point for considering the claims of various anonymous poet-heads of this and a somewhat earlier date. Stylistically it seems to be somewhat later than the Epimenides, which it resembles in the hair radiating from the crown and clustering in front of the ears, the somewhat pointed beard and the treatment of brow and cheek. ${ }^{57}$ The coin proves in fact how one preHellenistic Homer was conceived, whether the original was a statue, or whether, as is perhaps more probable, the type is numismatic; it marks a second stage in the evolution of the type, the first we know being represented by the Homereia of Sinyrna, with the long hair knotted behind over a fillet and the formal curls on the neck.

(viii.) Amastris.

Like Nicaea, this remote city of Paphlagonia appears to have no connexion with Homer apart from the old name of its citadel, Sesamus, which is mentioned in the Catalogue ( $I$. ii. 853), and it borrows at least one numismatic type (post, p. 320) from Smyrna. It was founded about the year 300 by

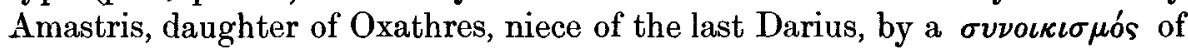
four ancient cities, of which Sesamus was one, 58 but in spite of numerous references to it in Lucian and elsewhere we know nothing of the town beyond a few inscriptions, nothing of the works of art and public buildings which made the younger Pliny in a letter to the emperor Trajan call it urbs elegans et ornata. The coins, however, are of extreme importance and interest, but

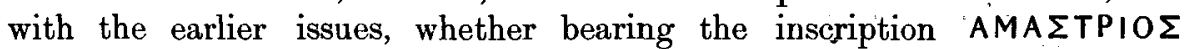
BA $\Sigma I A I \Sigma \Sigma H \Sigma$ or not, we have nothing to do. ${ }^{59}$ The Homer types, one of which appears to be reproduced in Camini, Iconografia, Pl. XXVII., are all of imperial date.

a. A. 1-15. Period of the Antonines.

Obv. OMHPOC. Bust of Homer r. wearing fillet; drapery visible on both shoulders; hair long, and falling on neck in wellmarked locks; beard somewhat long; chin projecting; eyes recessed, with well-marked eyelids and upward gaze;

57 The comparison should be made with the head in Munich (A-B. 423-4), or the still finer example in the Barracco collection, rather than with the poor and academic copy in the Vatican, from which the type is generally known.
58 See Strabo xii. 9; Pauly-Wissowa, i. pp. $1749-50$

59 Head $^{2}$, pp. 505-6; B.ll.C. Pontuc, ete. pp. 84-5. 
features clear-cut and of individual type; face not seen in full profile.

Rev. Undescribed. ${ }^{60}$

B. A. 1.05. [Pl. V. 19.]

Obv. OMHPOC. Bust of poet as above, but of coarser style; an attempt is made to render the further eyebrow as on $a$, but it is a failure.

Rev, AMACTPIAN $\Omega$ N. Hades seated l. holding sceptre, Cerberus at his feet. ${ }^{61}$

$\gamma$. E. 8. Period of the Antonines.

Obv. OMHPOC. Bust as above, of rougher workmanship.

Rev. AMACTPI AN $\Omega$ N. Tyche of Amastris seated $1{ }^{62}$

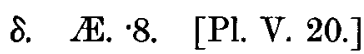

Obv. OMH POC. Bust of Homer r., fine style.

Rev. AMACT PIAN $\Omega$ N. Nike standing 1.63

є. A. 8 or 85 . Probably later than the reign of Marcus Aurelius (post, p. 320, note 69a).

Obv. OMH POC. Bust as above.

Rev. AMACTPIAN $\Omega$ N. River-god Meles reclining l. holding lyre in

r. hand, reed in 1. ; left arm rests on vase, whence water flows; in exergue $M \in \Lambda H C .64$

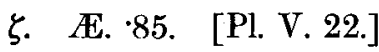

Obv. OMHPOC. Bust as above.

Rev. AMACTPIAN $\Omega$ N. River-god Meles as above, but holding uncertain attribute (reed?) in $\mathbf{r}$. hand. ${ }^{64 a}$

$\eta$. 2 E. 8. [Pl. V. 23.]

Obv. OMH POC. Bust as above.

Rev. AMACTPIC. Bust of Faustina-Tyche of Amastris r., veiled and turreted. ${ }^{65}$ Of fine style and fabric.

o. Obv. OMHPOC. Bust as above.

Rev. AMACTPIAN $\Omega$ N. Figure of Anaitis or Aphrodite seated r. (not a male figure, as given by Cuper: see post, p. 322). ${ }^{65 a}$

60 Bernoulli, Münzt. i. 1 ; said to be (1901) in Arolsen collection. The reverse is undescribed by him, and I have been unable to obtain any description of it from Arolsen.

61 lbid. No. 2. I have to thank Dr. Regling for a cast of this coin, which is now at Beriin.

${ }_{62}$ B.M.C. Ponfus, etc. p. 86, No. 13.

63 Ibid. No. 14.
64 Ibid. No. 15 ; Cuper, Apotheos. Homeri, p. 22 ; Hunter. Coll. ii. p. 233.

6ta B.M.C. Puntus, ctc, Amastris, No. 16.

65 B.M.C. Pontus, p. 86, No. 17.

65a Cuper, Apotheos. Homeri p. 22. This type is not published more recently, but is not necessarily suspicious. Cf. infra, p: $322, \mathrm{xv}$. 
It seems at first sight unlikely that the heads $a-\zeta$ can all be derived from one original. $a$ and $\zeta$, for instance, have fine and delicate features, and the recessing of the eyes gives an intensity to the gaze foreign to other coin types. $\zeta$, although so much smaller, is much better in style than $a$, though the latter is interesting as one of the few ideal portraits on coins in which the head is not represented in full profile, but shows the arch of the brow beyond the nose. There can be no doubt, however, that the two represent the same type reproduced from different points of view. $\beta-\varepsilon$ on the other hand are marked by clumsiness of style; the beard and hair are conventional and heavy and the treatment altogether careless, but, agreeing as they do in the externals of the type-the slightly bent neck, the fulness of hair on the forehead, the recessed eyes and prominent chin, the drapery on the left shoulder, the long locks on the neck behind and falling forward on to the collarbone, and a really long-haired Homer is as rare in existing monuments as we gathered it was in antiquity (supra, p. 305)-it is impossible to doubt the identity of type. Many of these details are peculiar among coin types to the Homer of Amastris, and it is noteworthy that, whereas late die-cutters constantly conventionalise or slur over details of feature and expression $^{66}$ they are usually faithful in reproducing characteristic attributes of a particular type. The coins of Amastris of better style, $a$ and $\zeta$, show a distinct effort to reproduce the style of the original; the worse ignore this utterly, aiming only at external fidelity: by the consensus of both something of the style as well as the externals of the originals may be recaptured. ${ }^{67}$

The distinctive features of this type $\mathrm{e}^{68}$ were recognised by Visconti in the so-called Apollonius of Tyana and its replicas, a view which Bernoulli is disposed to doubt on the ground that the coins "wegen ihrer wechselnden Typen' offer a precarious ground of identification. We have seen that, though the features vary somewhat, the essentials of the type are fixed, and it is not more unreasonable to base an argument on the coins of finer style than it is to take the best examples of the 'Apollonius'-as Bernoulli himself does-and use those for purposes of comparison. If the likeness between the coins and the 'Apollonius' is in itself convincing, this should suffice: that it is convincing, if we put aside the theory that coins can never be a basis for identification, is almost past doubt. The thick locks clustering on the forehead and falling on the neck before and behind, the drapery on the left shoulder in the two most careful replicas, the straight thin nose, short upper lip and prominent chin, the recessed eyes with their clearly marked lids-these are identical in both, and as different

${ }^{66}$ Cf. c.g. the bronze and silver OMHPOY coinage of Ios (supra, p. 13).

67 Viscontl's suggestion that, because Amastris was a colony of Smyrna, therefore the coin type was probably taken from the statue in the Homereion there, is quite unsupported by facts; the $M \in \wedge H C$ type $\epsilon$ is, however, of course due to the Sinyrnaean origin of the Amastrians.

48 For the Capitoline example Bernoulli i. Pl. III ; Bottari, i. p. 51; Helbig ${ }^{2}$ i. 503; more recently called Hesiod, of. Bernoulli i. pp. 26-7. 
from other Homer types as is the coin of Ios from the Hellenistic Homer of the British Museum. To say with Dr. Bernoulli that, because the 'Apollonius' has not the least relationship to the Hellenistic Homeric type, therefore it is probably not Homer, ${ }^{69}$ is surely misleading, since no single coin corresponds to that Homeric type, even where, as in the case of Smyrna $a$, the coin is known to represent an actual statue: the argument on à priori grounds therefore falls to the ground, and the positive evidence of the coins that a Homer type was famous at Amastris which corresponds with the 'Apollonius' even in detail may surely be accepted. Bernoulli justly notes the decorative character of the hair of the busts as belonging to painting rather than to sculpture. and suggests that the original may have been created by an artist of the second Attic school, to which indeed this idealising style also points; if its identity with the Amastris type is accepted, its date must be somewhat later, since the city of Amastris was only founded about the year 300, and the statue cannot therefore have been of earlier date. That it belongs to the later Attic school is, stylistically, highly probable. Attic artists were largely employed in the latter half of the fourth century in Asia Minor, and Queen Amastris, who finally became the wife of Lysimachus, may well have been a patron of art in her new-founded and eponymous city, to whose beauty Pliny later bears witness. The reason for the erection of the statue is obscure; we find it, as already said, in connexion with the type of the river-god Meles, which is borrowed directly from the probably almost contemporary Meles coins of the mother-city Smyrna, ${ }^{69 a}$ for any other connexion of Meles and Melesigenes with Amastris is still to seek. Most of the cities which struck coins bearing the portrait of Homer had some claim more or less direct to personal connexion with the poet; here it seems likely that the obscure Paphlagonian town, one of the four communities to make up the, new city of Amastris, either seized on its only ancient distinction, its mention in the Catalogue, or remembered that Smyrna was its mother-city and Homer in some sense a citizen of their own, and erected a statue of the poet, the commission being probably given to some famous artist, which would account for its popularity in Roman times. ${ }^{70}$ In later days the Homeric glories of Amastris were emphasised by a bold borrowing of the river-god of Smyrna, equipped with a lyre to make the connexion with the Homer of the obverse the more obvious. History as well as style points to the probability that the statue of Homer was erected by Queen Amastris for the adormment of her city soon after its foundation in 300 B.c.

The Meles type is then a reproduction of the coin issued by the river's

69 i. p. 21. The fillet is unquestionably larger than usual, as it is on some of the coins of Amastris, but this is a detail which varies so much that no great stress can be laid on it. Contrast, e.g., the broad fillet worn by the Homer of the Ios coins with the mere thread worn by the Hellenistic Homer of the Louvre. 69a These liave been with great probability assigned by J)r. Head to the reign of Marcus Aurelius (B. M.C. Ionia, p. 261); therefore the Amastrian issue is later than that reign.

${ }^{70}$ Bernoulli enumerates ten replicas, op. cit. i. pp. $27-8$. 
rightful owner, with the noteworthy addition of a lyre. No other river-god is found with this incongruous attribute, but it is impossible, it seems to me,

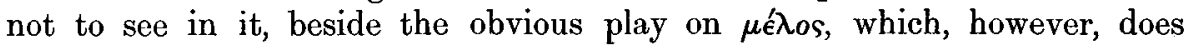
not occur at Smyrna, an allusion to Melesigenes, the singer who took his name from the river. Smyrna had no need of such a canting symbol : she had the river, and she had the cave in which Melesigenes composed his works; but the borrower Amastris is not content with the river-god unless his connexion with the Homer of the obverse, with which type alone he is found, is further explained. It is even possible that a picture or statue of Meles so conceived was placed near the Homer of Amastris, since the type is only found as the reverse of a Homer coin, whereas at Smyrna, where the type originated, it serves for obverse and reverse on coins of different issues. The only other similar type at Amastris, the river-god Parthenios, which is not found with this obverse, is of local origin and presents no special feature, another reason for assuming the lyre held by the Meles to be an allusion to the Melesigenes of the obverse.

One last feature common to the busts and coins must be mentioned, the curious blank look produced by the turning of the axis of the eyes outwards and upwards. This is noteworthy even on the coins, notably on $a$, where the head is seen on a larger scale, and must have been a marked feature of the original, as in fact it is of the copies. The effect of blankness and blindness is very marked, more so indeed than in any of the famous Hellenistic types except the Sans-souci bust (Bernoulli i. 2), in which both eyes are a restoration, and in an accomplished work of this date this cannot have been accidental.

It seems not unreasonable to hope that we have thus, with the help of the coins, re-instated a famous but disputed portrait as a Homer of the earlier part of the third century B.C., and have even in some degree recovered its artistic history. It remains to consider those Homeric coin types found in the older numismatists which modern scholarship cannot accept.

Dr. Bürchner, as already said, states that ten cities struck coins bearing Homeric types; Rasche in his first volume ${ }^{71}$ states that besides the eight here mentioned, Crete, Melos, and Myrina also issued them. The following list of Homeric apocrypha is probably incomplete but may be found useful.

(ix.) The so-called coin of Crete $^{72}$ should read IHT $\Omega N$, not KPHT $\Omega N$, and is no other than the Ios coin (Rev. Athena and palm-tree) above described, as Rasche in the second volume of his Lexicon (ii. p. 555) notes.

(x.) The coin of $M e l o s,{ }^{73}$

Obv. OMHPOC. Head of Homer r., wearing fillet,

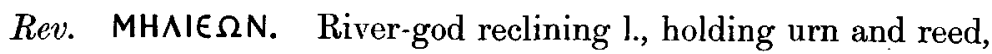

7 Lexicon i. part ii. p. 101.

72 Figured in Haym, Thes, Brit. part ii. p. 58 .

73 Numismat. Musaci Hon. Ariyoni. vol. i. section on Numismala Deorum, Heroum, etc. Pl. III. 15. (This book is unpaginated and the sections of plates separately numbered; the present comes towards the close of the book.) 
cannot now be traced, but looks in the engraving like a misreading of the familiar Amastris type, itself borrowed from Smyrna, with the river Meles, who usually holds lyre and reed: the urn may easily be a mistake for the much less obvious lyre. The form MHAIE $\Omega N$ is improbable, the river-god type unknown in Melos; probably therefore this is a mere misreading of the $M E \Lambda H C$ type, and not purely apocryphal.

(xi.) The coin of Myrina reading MVPINAI $\Omega N$ OMHPOC is mentioned by Hardouin, ${ }^{74}$ but beyond stating that it belongs to the reign of Nero he gives no further account of it, and the coin is apparently untraceable. There is no a priori evidence against its authenticity, but as things are it can only be considered doubtful.

(xii.) The coin of Chios given by Sestini, ${ }^{74 a}$

Obv. XIOE $\Sigma$. Bald bearded head of Homer facing, above taenia,

Rev. Sphinx,

is certainly apocryphal,

(xiii.) Gronovius' medal (Thes. ii. p. 20) representing Apollo side by side with 'Homer,' a common altar between them, is really B.M.C. Ionia, Chios, Nos. 122-41.

Obv. ACCAPIA TPIA Sphinx to $r$.

Rev. XI $\Omega$ N. Apollo with patera and Dionysos with cantharos and thyrsos facing, between them flaming altar.

(xiv.) The Homer of Guillaume Roville, called a 'Medaglia' in the Italian version of the Promptuarium Iconum, is a purely imaginary type, ${ }^{75}$ a conventional bearded head possibly derived from a contorniate, with a laurel wreath added.

(xv.) The Homer of Amastris given by Cuper (Apoth. Hom.) and mentioned above (p. 318) as $\theta$, may not be genuine, as its reverse, the Aphrodite-Anaitis type, is not recorded in imperial times, to which all the Homer types of Amastris belong, though it occurs on earlier coins; it may, however, be right enough, as the combination is at least not an obvious one for a forgery.

(xvi.) The WMHPOC type also given by Cuper (ibid. p. 23),

Obv. Homer type as found on contorniates,

Rev. Man leading horse,

is a contorniate misleadingly drawn; so are $(a)$

(xvii.) Cuper's other type,

Obv. Homer, as above, and $(b)$,

Rev. River-god, 
(xviii.) Fulvius Ursinus, Imagines, 1570, p. 20. These are like other contorniates more fully dealt with below. The writer is unable to identify three of the engravings in Gronovius, that with the small head on a large field, inscr. OMHPOC, that without an inscription, which may not be a Homer at all, and the OMHPOC head wearing a fillet; all are engraved in the text of vol. ii. p. 19 of the Thesaurus as if they were contorniates, but no reverse types are given.

Finally, Haym's 'Homers' (Thes. Brit. ed. 1763, vol. i. Pl. XIX. 2-3) rev. head of 'Thespis' crowned with ivy, AӨӨE, is in fact B.M.C. Attica, p. 86, Nos. 604 seqq.

Obv. Laureate head of Zeus $r$.

Rev. Head of Dionysus. A $\theta \mathrm{E}$,

the first $\theta$ is a misunderstood symbol. Haym's second variety, in which Zeus wears a fillet, is otherwise undescribed with this reverse, although Homer was, indirectly, claimed as Athenian by the historians Aristarchos and Dionysios, and, as we have seen, there was at least one statue to him in Attic territory.

Eight cities then claimed by their coinage a share in Homer ; and it is most unfortunate that in the long list of statues mentioned by ancient writers not one corresponds with these numismatic examples except the famous statue at Smyrna, which, though not expressly mentioned, is implied in the mention of coins and shrine by Strabo, and was seen in the fifteenth century. One of the remaining types can be recognised in the so-called Apollonius, but the remaining six are unknown, and likely to remain so. But their very variety, and the fact that not one corresponds with the famous and familar Homer types, may reasonably set us looking among existing busts and statues for types, not necessarily those on the coins, which may, like them, reproduce some of the different Homeric portraits so widely distributed over the ancient world.

A few words must be given to contorniates, since the Homer type on these pieces is widely known. Contorniates, a group of 'medals' so long classed as numismatic that it is hard to break away from the tradition, and call them frankly draughtsmen, have, as I have elsewhere pointed out, ${ }^{75 a}$ very small value as portraits. After Alexinder the Great, Homer is by far the commonest of these types, but, like most contorniate portraits, has no individuality, while the treatment of the hair and drapery belongs to the fourth century of our era. This WMHPOC type-so the word is almost invariably written-has no claim to rank even as a reflection of a Greek ideal portrait, and its interest chiefly lies in the testimony which its frequent occurrence bears to the popularity of Homer in the later Roman world, as do the scenes from Iliad and Odyssey so common as reverse types on the same objects. It is a curious fact that most of those personages represented on the coins, other than imperial portraits and 
the great majority of the myths, are Greek, though contorniates were used solely in the western world and are chiefly found in Italy. Against Horace, Virgil, Terence, Sallust, Apuleins, Roma, the Wolf and Twins, the Rape of the Sabines, and one or two more must be set Homer, Alexander, Demosthenes, Euripides, Olympias, Anaxarchus, Pythagoras, Apollonius of Tyana, Sarapis, Helios, and the very numerous scenes from Greek legend and mythology; the scenes from daily life are, on the other hand, entirely Roman. The value of the heads as portraits is almost nil. ${ }^{76}$ It is a curious and apparently unnoted fact that none of the numerous Homer types has any legend on the reverse; the name on the obverse is variously written $W M H P O \Sigma, W M H P O C$, and very rarely OMHPOC, but the type varies very little. The reverse types are as follows :-

a. Ceres, the Emperor, Jupiter, Victory, Earth, and Ocean. (Sabatier, Médailles Contorniates, xii. 6 ; Coh. 62 .)

B. Cybele and Atys in quadriga. (Sab. xi. 6; Coh. 63.)

\%. Bacchus, Silenus, and panther. (Sab. xi. 9; Coh. 64.)

$\delta$. Legend of Dirce. (Sab. xi. 9 ; Coh. 65)

є. Groom and horse. (Sab. vi. 3; Coh. 66; Cuper, Apotheos. Homeri, p. 23.)

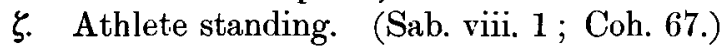

$\eta$. Huntsman attacking boar. (Sab. ix. 9; Coh. 68.)

$\theta$. Victorious quadriga r. (Sab. vii. 5 ; Coh. 69.)

¿. Victorious quadriga, full face. (Coh. 70.)

$\kappa$. Alexander? (usually called huntsman or Emperor) attacking a lion. (Fulv. Ursinus, Imagines, p. 20; apparently the earliest reproduction of a contorniate.)

$\lambda$. River-god holding reed, reclining l., leaning on urn. (Cuper, Apotheos. Homeri, p. 23; for other possible types cf. supra, p. 323.)

Neither of the last has been hitherto identified as a contorniate, but the identification is a certain one both from the types of obverse and reverse and the spelling of Homer with an $\omega$. The last, $\lambda$, is of special interest, as the type of the river-god is not elsewhere found on contorniates save in the case of a copy of the Nilus of Alexandrian coins in the British Museum (Num. Chr. 1906, Pl. II.). Moreover, it is an unquestionable example of the rare class of contorniate reverses copied direct from coins, the original in this case being the MEAHC coins of Amastris already noted, and it is thus directly connected with the obverse type, which is very rarely the case with contorniates.

In these contorniates then we have objects essentially popular, on which the die-cutter produces portraits marked by the peculiarities of hair

\footnotetext{
${ }^{76}$ There are perhaps three exceptions, the Lysippic head of Alexauder, the COA $\Omega N O C$, a faithful copy of a famous Roman gem signed by the engraver Solon, and the type of

Pythagoras with obverse head of Helios. See my articles in Num. Chr. 1906, p. 17, and in Papers of the British School at Rome, 1905, p. 310 .
} 
and dress of his own times, which is exactly what the die-cutter of the portrait coins does not. No stronger argument for the authenticity of the latter can be adduced than a comparison between their carefully marked and often archaic details and the imaginary portraits created by the makers of contorniates after the fashion of their own times.

In the Homer of monumental art only the later ideal is commonly recognised, and though the vindication of the value of coin types here attempted may re-instate Visconti's second Homer type, the so-called Apollonius, as a copy of the Homer of Amastris, we are still no nearer to discovering the earlier and nobler conception presented by the coins of Ios and Smyrna on a larger scale. It is not perhaps too much to hope that by their aid some portrait head may be identified, more in accordance with the dignity of these earlier types.

To sum up, we can trace three stages in the Homer of the coins, and may therefore assume them for other forms of art. The coins of Smyrna represent Homer under the aspect of an Olympian; seated apart he rests his head on his hand, holding in the other, negligently and as an attribute, the immortal scroll. On certain coins of Cyme he appears as like a Zeus as mortal may, with scroll in place of thunderbolt or Victory. On the coins of Chios $a$ he has become the human poet, and the scroll, no longer an attribute merely, forms part of the motive of the statue; on Chios $\beta$ Homer has become the reciter, and the scroll is essential to the motive of the work. These three stages, the Olympian, the poet, and the minstrel, correspond to all that we know from other sources of the development of Greek portrait art. In the case of Homer it, cannot be doubted that the last stage, artistically speaking, is represented in the familiar Hellenistic type; an intermediate stage and earlier tradition-if we may judge from the head only-is represented in the 'Apollonius.' Portraits such as those on the coins of Ios and Smyrna have not thus far been identified on a larger scale, since Homer types have as yet been judged by their conformity or non-conformity with the Hellenistic types; but the same tendencies can be traced in the Lateran Sophocles on the one hand with its strongly marked idealism so different from the earlier and severer type, on the other in the increasing grotesqueness which marks the later portraits of Socrates. Taking all the portraits together, as well Hellenistic busts as the coin-types of six centuries, we may say of the coins of Ios as Pliny said of the Alcman of Calamis, Homerus poeta nullius civitatis est nobilior.

Katharine A. Esdaile. 